\title{
The Observatory Gravels and the Travellers' Rest Pit, Cambridge, England
}

\author{
R.G.West ${ }^{1}$, P.L.Gibbard ${ }^{2 *}$ \\ 13 A Woollards Lane, Great Shelford, Cambridge CB22 5LZ, England \\ ${ }^{2}$ Cambridge Quaternary, Department of Geography, University of Cambridge, Cambridge CB2 3EN, England \\ *corresponding author (email: plg1@cam.ac.uk)
}

\begin{abstract}
An examination of the past descriptions of the Pleistocene Observatory Gravels and the sediments of the Travellers' Rest Pit of north-west Cambridge has illustrated their relation to the local landscape in terms of sediments and age. The Travellers' Rest Pit sediments, which include gravels and 'loams', represent aggradation and alluviation/colluviation in a former drainage way which resulted from diversion to the west of the Cam valley drainage by glaciation in the Fenland in the Late Wolstonian Stage. The drainage way may have carried both Cam valley catchment waters and proglacial waters. The Travellers' Rest Pit gravels and 'loams' now lie on a ridge of Gault and Chalk Marl. The Observatory Gravels occur on the western slope of this ridge, at a lower level than the sediments of the Travellers' Rest Pit, and are associated with the incision of the Washpit Brook valley, on Gault Formation bedrock to the west of the Observatory slope, at a later date. The periglacial ground-ice structures and palaeontology of the Travellers' Rest Pit sediments are described, The Palaeolithic archaeology contained within the sequence, bears comparison with Palaeolithic finds elsewhere in Late Wolstonian proglacial gravels of the Fenland margins.
\end{abstract}

Received: 00/00/2017

Recent evaluation of the Pleistocene of the Fenland basin has demonstrated the importance of gravel and sand sequences to the evolution of the region. These sequences have shown that the basin has undergone extended periods of cold-climate weathering and at least three periods of glaciation during the Middle to Late Pleistocene. In particular, glaciation of Fenland during the late Middle Pleistocene Wolstonian Stage (c. 380-125 ka) resulted in deposition of meltwater-derived accumulations on the basin margins (e.g. Gibbard et al. 2009). In this context the Observatory Gravels and the Travellers' Rest Pit occupy a significant place in the geological history of the Cambridge district. The present account analyses the descriptions of the gravels and associated sediments, and offers new interpretations of these critical sequences. 
Worssam \& Taylor (1969) described in detail gravels recorded in pits in the area mapped as Head Gravel and Observatory Gravels associated with a low ridge of Gault Formation and Chalk Marl (formally Lower Chalk, now West Melbury Marly Chalk Formation: Mortimore 2014) running north-west of Cambridge (B.G.S. Sheet 188) (Fig. 1). The gravels were divided into Head Gravel and Observatory Gravels, the latter including the gravels associated with the ridge. More recently, the Observatory Gravels came under examination by Boreham (2002; Boreham et al. 2010; contributions in Bowen 1999) and by Green (2008).

The Observatory Gravels were first described by Penning \& Jukes-Brown (1881) from pits on the western slope of the ridge (NGR TL 431956), near the University Astronomical Observatory. The Observatory Gravels of Worssam \& Taylor (1969) also included the gravels of a more recent pit, the Travellers' Rest Pit, at a higher level in the upper part of the ridge (NGR TL 431599), first described in detail by Marr (1920). The Gault Formation underlies both sites.

However, the sequences in the two areas are very different, as are their heights (Fig. 2a). At the lower site near the Observatory, 12 feet $(3.6 \mathrm{~m})$ of gravel were recorded by Penning \& Jukes-Brown (1881, p. 89), base at c. 20 m O.D. They noted that the Observatory Gravels were "banked up against the south-west side of the Chalk Marl ridge". On the ridge, the gravels of the Travellers' Rest Pit showed up to $c .6 \mathrm{~m}$ in thickness at $c .21$ to $26 \mathrm{~m}$ O.D., with a complex sequence involving stratified gravels. It is clear that separate descriptions are required, one for the Travellers' Rest Pit on the ridge, and the second for the Observatory Gravels on the west slope of the ridge.

\section{The Travellers' Rest Pit}

The significance of the Travellers' Rest Pit gravels lies in their height on the ridge at c. 21 to $26 \mathrm{~m}$ O.D., higher than the local fluviatile terraces of the Cam valley, in the considerable detail of the succession, and in the presence of non-marine shells and Palaeolithic implements. The Travellers' Rest Pit was described by Marr (1920, 1926), Marr \& King (1928, 1932) and Paterson (1940). These authors gave detailed descriptions of the sequence of sediments. There are also invaluable photographs of the sections by L.G. Morris, R.H. Rastall and W.B.R. King held in the University's Sedgwick Museum Archives. These photographs have been examined and where possible the sediment units reinterpreted including the application of the standard facies codes (modified from 
Miall 1978; Eyles et al. 1983). Useful sections across the ridge, which reaches a height of $c .26 \mathrm{~m}$ O.D., were given by Marr (1920) and Marr \& King (1932). Figure 3 shows the position of Marr's sections, based on a plan in the Sedgwick Museum Archives.

\section{Description of the sections}

Marr (1920) divided the sequence seen in the southern of the two pits at the Travellers' Rest into four units, total thickness 5 to $6 \mathrm{~m}$ :

Upper evenly-bedded gravels, up to $c .0 .5 \mathrm{~m}$ (facies Gms)

Sandy loams with scattered flint pebbles and occasional seams of gravel, up to $c .1 \mathrm{~m}$ (facies Frr)

Unevenly-bedded gravels, up to 2 to $3 \mathrm{~m}$ (facies Sp-Gms), includes two seams of 'loam' (facies $\mathrm{Fm})$

Lower evenly-bedded gravels, up to to 2 to $3 \mathrm{~m}$ (facies $\mathrm{Gms}$ )

Gault Formation, clay bedrock

Marr (1920) figured a section in the pit at the south-western end of the north-western face of the south pit, labelled so in photographs held by the Sedgwick Museum Archives (Figs 4, 5). The lower evenly-bedded gravels (the major bed in the pit) show varying degrees of coarseness and contain seams of sand. Marr noted that these bedded gravels formed the bulk of the pit. Large boulders, up to a foot $(c .30 \mathrm{~cm})$ in diameter, are present, listed by Rastall \& Romanes (1909). Bedding appears mainly horizontal (facies Gms) but includes a c. $20 \mathrm{~cm}$ thick lens of parallel crossbedded sand (facies $\mathrm{Sp}$ ) near the base. The gravels are overlain unconformably by the unevenlybedded gravels, with cross-bedded (trough) sands (facies St) filling an elongate channel-like form (c.1.2 $\mathrm{m}$ thick) which grade upwards from fine-grained gravels at the base (facies ?Gms), cut into the lower evenly-bedded gravels. According to Marr (1920, p.213) these consist of "materials very similar to those of the underlying deposits, apart from the irregularity of their stratification, save that massive deposits of gravel with a loamy matrix devoid of stratification are frequent. Lenticular deposits of finely-bedded sand occur at various horizons of the upper series, usually filling small erosion channels and showing false-bedding parallel to the floors of the channels". The sediment body in Marr's figure and the photograph (Figs 4, 5a) is evidently one of these channels. In the image, the channel shows an upward-fining trend from gravels at the base to sands at the top. Indeed, he noted that "Many boulders also occur in the unevenly-bedded series, especially in its basal deposit, which is usually a coarse ferrugineous gravel” (Marr 1920, p. 213). 
Although Marr described the loam as directly overlying the unevenly-bedded gravel the photographs show that a second bed of medium gravel (facies $\mathrm{Gms}$ ) is $c .30 \mathrm{~cm}$ thick and overlies the sands beneath with an erosional base. The sandy loams (sandy clayey silt) are described as chocolate-brown, with scattered flint pebbles and occasional seams of gravel (facies Fcr). Marr considered that they were laid down not long after the deposition of the underlying unevenly-bedded gravels. The loams appear to be involved in involutions adjacent to the top of the unevenly-bedded gravels and also to fill the 'erosion channels' (now interpreted as massive thermal contraction cracks, see below) observed in the sections, from which Marr considered that they represented the sediment laid down over a wider area than that in which they now occur. The upper evenly-bedded gravels are sandy and stratified, reaching a thickness of only c. 30-50 cm, and are divided sharply from the underlying sediments, "only recently exposed as the pit cut backwards" (Marr 1920, p.213).

Further observations on the Travellers' Rest Pit were made by Marr (1926), Marr \& King (1928, 1932) and Paterson (1940). Marr (1926) discussed the relation of the gravels to clay with 'race' (concretions) and flints found near surface to the east of the ridge, eastwards of the Huntingdon Road. Marr \& King (1928) noted that the uneven-bedded gravels were even-bedded in places with alternation of gravel, sand and fine loams. In two seams of such loam (facies Fm) a shell fauna (including Columella columella) was identified, indicating cold conditions. They described a section (Marr \& King 1928, p.308) where the unevenly-bedded gravels were overlain by "a few feet of blue clay with scattered flints, weathering to a chocolate-brown" (facies Dmm) (Fig. 5b). It was thought to resemble a boulder clay (glacial diamicton) and compared with the clay which contained Chalk boulders found in a field $c .100$ yards $(c .100 \mathrm{~m})$ to the north-west. The upper evenly-bedded gravels were seen to pass over the main mass of blue clay and to cut off the top of the filling of the large contraction cracks. The beds of loam in the sections were considered possibly to be loessic in origin, deposited on the surface of the floodplain.

In their final contribution on this succession, Marr \& King (1932) regarded the unevenlybedded gravels as outwash gravels from an oncoming ice-sheet and made a comparison with outwash deposits of the floodplain of the Malaspina Glacier in Alaska. They noted that "On the floodplain of the glacier streams issuing from the ice deposit gravels of various degrees of coarseness" (Marr \& King 1932, p.175), and in depressions finer sediments are deposited, with a fauna including the mollusc Limnaea. The loams with a fauna at the Travellers' Rest Pit were described as well laminated and suggested a similar environment. They concluded their paper with a discussion of the relation of near-surface clays in the area to the east of Travellers' Rest Pit Gravels. 
They drew a diagrammatic section across (c. SW-NE) the Huntingdon Road showing the relation between the Travellers' Rest Pit gravels and the clays and gravels to the north of the road at a lower height (Fig. 6).

Paterson (1940) also described sections at the Travellers' Rest Pit. Considering Marr's sequence, he wrote "the lower even-bedded series, laid down in quieter waters than the torrential flows which deposited the immediately overlying uneven-bedded series, which is characterised by strong current bedding" (Paterson 1940, p. 102). He paid particular attention to Marr's wedge-form channels, interpreting them as frost-cracks and comparing them with what he had seen on expeditions to the Canadian Arctic. He also described the involutions seen near the top of the sections and related them to small polygonal structures observed in the Arctic, a result of cryoturbation. He mentions chalk pebbles in the material in certain pockets, appearing derived from the overlying upper evenly-bedded series. Possibly these originated from the Chalk Marl outcrop a short distance to the south of the Travellers' Rest Pit on the ridge and north-east of the Observatory (Fig. 1).

The most recent contributions concerning the Observatory Gravels and Travellers' Rest pit have been made by Boreham (2002; Boreham et al. 2010), examining the place of these gravels in the Cam Valley sequence, and by Green (2008), who described the result of two boreholes made just outside the margins of the Travellers' Rest pit (positions shown in Fig. 3). The boreholes showed a light brown and white gravel (3$4 \mathrm{~m}$ thick) on weathered Gault Formation, and overlain by a brown and light brown gravelly sand (2-3 $\mathrm{m}$ thick). These beds appear likely to represent the lower evenly-bedded gravels and the unevenly-bedded gravels of Marr (1920). In Green's borehole 1 a bed $(20 \mathrm{~cm})$ of very pale blueish grey silty clay was penetrated at c. 22.6-22.8 m O.D. This bed appears to represent the 'loam' horizon of Marr (1920). The detailed clast analyses of the lower gravel in the boreholes show an abundance of flint and chalk, but a rarity of quartz, the last contrasting with the quartzite-rich gravels of the proglacial sediments of the eastern and southern side of the Fenland (Gibbard et al. 2009). These analyses and the height determinations add considerable detail to our knowledge of the Travellers' Rest pit gravels and 'loam', indicating a widespread occurrence of Marr's (1920) sequence.

\section{Thermal contraction cracks}

Marr interpreted the wedge-form structures seen in the sections at the Travellers' Rest Pit as "channels due to subterranean erosion" (Marr 1920, p. 213). He noted the channels were of various sizes, some 'incipient', and also noticed the polygonal arrangement of the channels as the pit faces 
were cut back. Paterson (1940) re-interpreted these structures as frost cracks, comparing them with structures described by Leffingwell (1919) in Alaska and those he had seen in the Canadian Arctic.

The contraction cracks (ice-wedge pseudomorphs) were figured by Marr (1920) and Paterson (1940), and there are also good photographs of them in the Sedgwick Museum's Archives and in Worssam \& Taylor (1969). Two types occur. There are various sizes of crack (intra-formational) in the lower evenly-bedded gravels, and there are massive wide cracks which underlie the upper evenly-bedded gravels and which have received on collapse the 'loams' which overlie the unevenly bedded series of Marr (1920) (Fig. 4). The latter forms resemble the type 2 contraction cracks at Somersham, which penetrate the Devensian Knobb's Farm Gravels (West 1993). There is also a crack which suffered thaw subsequent to the formation of the upper evenly-bedded gravels of Marr (1920) (Fig. 5c). The cracks indicate times of permafrost as the lower evenly-bedded gravels accumulated and a later period of permafrost which developed before the accumulation of 'loam' on the surface of the gravel plain and the deposition of the near-surface, upper evenly-bedded gravels.

\section{Involutions}

Involutions associated with the surface of the unevenly-bedded series are figured diagrammatically by Marr (1920) (Fig. 4). They were later described by Paterson (1940) in much more detail. He compared them with soil polygonal structures in the Arctic. He distinguished different types of pocket, showing their polygonal nature by excavation, with detailed illustrations of sections showing truncated pockets, walls of upturned gravels with flint and chalk pebbles, a globular pocket with infilling of the upper evenly-bedded gravels, and superposition and decalcification of pockets.

The photographs in the Sedgwick Museum Archives show these involutions very well (Fig. 5a, b). They appear as drop structures of overlying sediments, particularly loams, separated by pillars of the underlying unevenly-bedded series of gravels. The interpretation of the origin of the involutions is made problematic by the possible polygenetic origin of these features, but the relation of the structures to the sequence of sediments would suggest they belong to the class of thermokarst involutions described by French (2007), formed in water-saturated sediments by loading during permafrost degradation. Some upward protrusions of gravel resemble diapirs. They appear to be of later age than the filling of the large contraction cracks with the overlying loam, but predate the deposition of the overlying upper evenly-bedded gravels, which truncate the tops of involutions and the large contraction crack fillings. The truncation of some pockets by the upper evenly-bedded gravels, which also fill other pockets, indicates a complex sequence of involutions at the time 
between the cessation of the deposition of the unevenly-bedded series and the upper evenly-bedded gravels (Fig. 5b).

\section{Palaeontology}

Marr \& King (1928, p.308) described the discovery of shells in two seams of laminated loam separated by "only an inch or two of gravel" in an evenly-bedded part of the uneven-bedded series. They were identified by Kennard \& Woodward in an Appendix to the paper as Limnaea truncatula, Pupilla muscorum, Columella columella and Succinea oblonga. These authors commented that "This faunule indicates cold conditions. It should be noted that truly aquatic species are absent. Three are damp-loving land species, whilst Limnaea truncatula, represented by a single dwarfed example, will often flourish in a damp puddle" (p.312). Marr commented that mammalian remains were very scarce, only four recorded, comprising including two horse teeth, an astragalus of deer and a caudal vertebra, possibly of Rhinoceros.

\section{Archaeology}

Palaeoliths are frequently found in the proglacial gravels of the Tottenhill glaciation on the eastern and southern margins of Fenland and also in terrace gravels of the rivers draining into the basin (Gibbard et al.2009). In the case of the proglacial gravels, the artefacts must have originated in the Fenland during the Hoxnian Stage or earlier Wolstonian times, and were reworked during the glaciation.

Reed (1897, p. 238) noted that "the scarcity of implements around Cambridge is remarkable and difficult to explain, for in the neighbouring valleys they occur in considerable abundance". The neighbouring valleys rich in Palaeolithic artefacts include the Great and Little Ouse valleys with their terrace gravels, and the Lark valley, where proglacial gravels are rich in palaeoliths. The difference is likely to be associated with the relative absence of terrace gravels of Wolstonian age in the Cam valley, only well-represented by the Travellers' Rest Pit with its abundance of artefacts. The pit produced many Lower Palaeolithic implements, described and figured by Marr (1920). M.C. Burkitt gave additional comments in an Appendix to that paper and the assemblage was also discussed by Wymer (1985). The provenance of the implements was generally uncertain. Wymer (1985, p. 77) commented that "nearly everything is rolled or very rolled and probably came from the lower evenly-bedded series". Burkitt noted that many recall the Lower Palaeolithic industry at Three Hills, Mildenhall, one of the many Palaeolithic sites of the Fenland margin associated with outwash from the Tottenhill Glaciation of the Late Wolstonian Stage (Gibbard et al. 1992, 2009). Marr 
recorded that patination showed that many implements lay on the surface and were exposed to weathering before incorporation in the gravels, as also described at Three Hills.

\section{Interpretation}

The sequence at the Travellers' Rest Pit tells a complex history of a sequence of gravel-bed fluviatile accumulations at an elevation of c.21-27m O.D., higher than the local fluviatile terraces of the Cam valley (below c.23m O.D.) (Worssam \& Taylor 1969). Marr \& King (1932, p.175) concluded that the unevenly-bedded gravels were "outwash gravels from an oncoming ice-sheet before it reached Cambridge", making comparisons with an outwash plain in front of the Malaspina Glacier in Alaska. The presence of large boulders in the lower evenly-bedded series, reportedly "chiefly in the basal deposit" (Marr 1920, p.213), indicates inundation of the Gault Formation, puddled in places below the gravel, a result of a rise in water level and the arrival of a gravel-bed river of considerable energy. It also reflects a common phenomenon of the occurrence of a remanié or gravel-lag deposit often composed on partially abraded clasts at the base of fluvial deposits, these accumulations also commonly including artefacts and vertebrate skeletal elements (cf. Lewin \& Gibbard 2010). The width of the river to the south-west is limited, as shown by the relation of the gravels to the valley of the Washpit Brook (Fig. 1), giving an approximate width of the river of 400-500 $\mathrm{m}$ (see below). To the north-east, in the direction of the present Cam valley, the gravel is cut off by the slope to the terraces of that river, as indicated by Marr \& King's (1932) sketch (Fig. 6).

With the recognition of the Fenland Tottenhill glaciation and its extent in southern Fenland (Gibbard et al. 1992, 2009; West 2017), it would seem reasonable to interpret the evenly-bedded gravels as deposits of a diverted River Cam, the former valley blocked by ice entering the late Wolstonian valley and diverting the stream to a course of drainage to the north-west (i.e. to an icemarginal position). This would account for the composition of the gravels, including the erratics, derived from upstream Cam valley gravels and upland, with Anglian Lowestoft Formation till in the catchment, and also for the presence of derived palaeoliths from surfaces of the Cam valley catchment. In this respect, Penning \& Jukes-Brown (1881) also related the gravels near the Observatory to a former course of streams of the Cam valley. The direction of flow of the stream is clearly indicated by the downslope of the mapped spread of the Observatory Gravels northwards to Girton (Figs 1, 2b). Worssam \& Taylor (1969) reported foresets inclined to the north in the gravel at Girton College. 
The unconformity between the lower evenly-bedded gravels with their contraction cracks (icewedge pseudomorphs) and the unevenly-bedded series clearly indicates a change in conditions of deposition, recognised by Paterson (1940, p.102) as a change to "torrential flow", with Marr \& King (1932) regarding the unevenly-bedded series as glacial outwash. The change from the evenlybedded gravels to the unevenly-bedded series might then relate to a change in the fluviatile regime resulting from the arrival of meltwaters in the valley containing the river. Laminated loams in the unevenly-bedded series contain the shell fauna indicating cold conditions, within the gravels of Marr \& King's (1932) outwash deposits.

However, in reality all the stratified facies and associated structures identified in the Travellers' Rest Pit sections indicate that the deposits accumulated in a braided-river environment. The consistent association with climatic indicators such as ice-wedge casts, solifluction deposits and cryoturbation structures indicate aggradation under a predominantly periglacial regime. This is strongly supported by the facies present which typify seasonal or glacial flood-dominated rivers in the modern Arctic (Miall 1977, 1978, 1996; Rust, 1978a, b; Lewin \& Gibbard, 2010; van Huissteden et al. 2013).

The sequence following the unevenly-bedded series is complex. Overlying them Marr (1920, p.213) described "chocolate-brown sandy loams with scattered flint pebbles", and "seams of gravel occur in them occasionally". The loams are similar to the sediment filling the large contraction cracks. He recognised that the loams must have been 'laid down over a wider area in which they now occur". They appear to be part of an alluvial sheet over the gravel plain, mainly at a period later than the formation of the large contraction cracks, the filling of which connects with the alluvial sediments, as noted by Paterson (1940). They are sediments of a periglacial environment, likely to include aeolian, loessic and cover-sand fractions. From the photographs it is difficult to reach a conclusion regarding the origins of this material. However, experience from other areas suggests that the loam may represent an alluvial/colluvial deposit, including slope wash under a periglacial regime. The degradation of permafrost indicated by the large contraction cracks appears connected with the deposition of the loams. The development of an alluvial sheet over the gravels suggests a change to quiescent conditions, undrained, on the gravel plain, if not a cessation of flow in the particular area, with formation of the involutions at times. Thawing of the permafrost which produced the large cracks may have been facilitated by the deposition of the loam under watersaturated conditions, also possibly by local ponding and thermal erosion. 
The origin of Marr's loams of his earlier paper (Marr 1920) is not straightforward. Later, Marr \& King $(1928$, p.308) provided more information relating to the loams. On the south-eastern face of the pit they described a significant section (the channels referred to are the large contraction cracks): "Here the uneven-bedded gravels are succeeded by a few feet of blue clay with scattered flints, weathering to a chocolate brown, the weathered part becoming very compact and having much stalagmitic deposit within it. It resembles boulder clay, except that boulders, if they occur, are sparsely distributed, but it is probable that this clay is the continuation of the clay which contained Chalk boulders and was found in a field 100 yards or so to the north-west. There seems no doubt that the clay filling the channels is the decalcified base of this clay. The Upper evenbedded gravels which cut off the top of the channels was also seen passing over the main mass of this blue clay". Finally, the upper evenly-bedded gravels, very sandy, with chalk pebbles, were deposited unconformably over underlying deposits, indicating a late-stage insignificant renewal of fluvial conditions on a floodplain.

The upper part of the sequence thus represents a cessation of fluvial conditions, development of large contraction cracks, deposition of the loams, thawing of permafrost, development of contraction crack fills and involutions, and finally resumption of fluvial conditions. If the interpretation of the blue clay as a diamicton of glacial origin (e.g. a mass-gravity flow: e.g. Collinson and Thompson, 1982; Gibbard, 1994; Lewin \& Gibbard 2010) is accepted, then it would imply that a glacier margin, related to the displacement of the river westwards, had encroached the gravel plain, with cessation of fluvial conditions and the deposition of the loams, later affected by thermokarst involutions and contraction crack filling in a saturated landscape, with a final renewal of fluvial conditions.

Beyond the exposure, the Geological Survey Cambridge 1:50 000 sheet 188 shows the Travellers' Rest Pit gravel continuing in a northerly direction, north of Huntingdon Road, Cambridge, beneath Girton College (c. $1.8 \mathrm{~km}$ ) and Girton village for c. $2.5 \mathrm{~km}$ (Fig. 2b). This extension is confirmed by boreholes put down for the Cambridge Northern By-Pass road (source: BGS), in which boreholes TL46SW102-104; c. $21.7 \mathrm{~m}$ O.D. prove gravels up to $4.55 \mathrm{~m}$ thick resting on Gault Clay bedrock (Figs 1, 7). Here the spread is approximately $400 \mathrm{~m}$ in width, confirming the observation noted above. The gravels can be traced a further $c .1 \mathrm{~km}$ northwards to Red House Farm, Girton, where they are $1.8 \mathrm{~m}$ thick resting on Gault Formation clay (TL46SW136; $19.6 \mathrm{~m}$ O.D.). 
The ridge holding the Travellers' Rest Pit gravels thus appears to be a remnant of a stream which carried the Cam drainage temporarily to the west, forced aside by the ice which entered the main Cam valley to the east. The unevenly-bedded gravels possibly relate to meltwaters from the glacier. The drainage returned eastwards to the old valley as the ice retreated, not to the west where the western limit of the stream, mentioned above, limited movement in that direction. The denudation leading to the Cam valley Low Plain of Sparks (1957) exposed the ridge as it is seen today.

This interpretation has some similarity with that of changes in the Cam River system by Penning \& Jukes-Brown (1881) in their Geological Survey Memoir. They proposed an Ancient River System, predating the present system, which followed a course north-west of Cambridge towards Oakington and included the gravels of the Observatory area. Gravels of the Present River System first followed a parallel course, which later moved north-eastwards. The geological map of this Memoir shows clearly the position of the Ancient System, the later parallel position of the Third Terrace of Worssam \& Taylor (1969) and the movement to the north-east of the younger terraces. The whole sequence, shown clearly by Worssam \& Taylor (1969) in their figure of the terraces of the River Cam, appears to have an origin in the changes following the diversion of the Cam by the ice of the Tottenhill Glaciation and a later recourse to the valley exposed on deglaciation.

The alignment of the Cam towards the north-west implies that the river was forced to flow in this direction by the arrival of the Tottenhill ice in the area immediately north of Cambridge, broadly between Longstanton and Milton. This prevented the river from continuing on a northnortheastwards alignment. In addition, it was unable to follow an ice-front parallel course to the east since it could not overtop the bedrock barrier of the high ground at Hare Park, Newmarket, $15 \mathrm{~km}$ to the east-southeast (West, 2017). Once the ice barrier was removed, following deglaciation, the river re-established its north-northeastwardly course towards Ely. This course is that represented by Terrace 3, underlying Histon Road, Cambridge at 13 m O.D. (Fig. 1). Here latest Wolstonian gravel and sand resting on Gault Formation at 5 m O.D. is overlain by the Ipswichian-age Histon Road Member interglacial to Early Devensian-age deposits (Sparks \& West 1959), the sequence indicating that a substantial incision phase occurred following the glacial retreat (Boreham, 2002; Boreham et al., 2010).

\section{Gravels in the Observatory area (Observatory Gravels)}




\section{Description of the section}

Gravels in pits near Gravel Hill Farm, adjacent to the University Observatory (NGR 431956) (Fig. 1), were described by Penning \& Jukes-Browne (1881). A section $12 \mathrm{ft}$ (3.6 m) in depth showed from the surface:

- $6 \mathrm{ft}(1.8 \mathrm{~m})$ Gravel interrupted and disturbed by pockets filled with contorted brown sand and occasional flints, with films of carbonate of lime lining the bottom. This is presumably due to the dissolving away to the numerous chalk pebbles (facies Gmm-Dmm) (cf. reprecipitation of calcite: Murton et al. 2003).

- $6 \mathrm{ft}(1.8 \mathrm{~m})$ Fine gravel, rather irregularly bedded, consisting of nearly $50 \%$ of chalk pebbles, the rest flint, with a few hornstones, quartzites, \&c., one large boulder evidently derived from the neighbouring Boulder Clay (facies ?Gms).

\section{Interpretation}

This pit is on the slope towards the valley of the Washpit Brook to the west, which cuts into the Gault Formation, and thus is at a lower level than the Travellers' Rest Pit (Fig. 2a). The gravels appear banked against the Chalk Marl bedrock outcrop near the ridge top, so that the chalk content is likely to be derived from the Chalk Marl. In contrast, the Travellers' Rest Pit gravels clearly rest on Gault Formation, which replaces Chalk Marl to the north. Penning \& Jukes-Browne (1881) recorded that the gravel thinned out at $c .80 \mathrm{ft}(24 \mathrm{~m})$ above sea level, but in the large pits near Gravel Hill Farm the base of the gravel is about 18 or $20 \mathrm{ft}(c .6 \mathrm{~m})$ lower. The western limit of the gravels in the Washpit Brook valley was shown by Marr in his 1916 sketch of the area (Sedgwick Museum Archives) and is marked in Figure 1.

The position and description of the section suggest that the sediments are a result of gravitational downslope mass-movement into the valley of sediments derived from erosion of the Chalk Marl and from the gravels at a higher level, taking place as the valley of the Washpit Brook developed (see below), so giving a western limit of the distribution of the Travellers' Rest Pit gravels to the west. The upper part of the section clearly shows the influence of cryoturbation on the sediments. The mixture of pebbles in a non-durable, poorly or unsorted matrix strongly suggests intermixing of material from the immediate vicinity, derived from local sources subjected to cold climate weathering. The depth of incision in the Gault Formation in post-Travellers' Rest Pit time is in the order of $10 \mathrm{~m}$. 


\section{Post-Travellers' Rest Pit Gravels time}

The degree of denudation of the Cam valley in this period is shown by the incision of the Washpit Brook in the Gault Formation, arising near the Observatory pits at a height of c.15 m O.D., c.12m below the height of the ridge (Fig. 1). The head of the Washpit Brook valley is isolated from the Cam valley and forms a wide enclave in the $15 \mathrm{~m}$ contour, appearing to be reLd to the nearby Trinity Conduit Head. This enclave drains through a narrow exit north towards Girton, west of the Travellers' Rest Pit ridge, then north to the Great Ouse, falling to 10 m O.D. just north of Girton. Thus, this valley must have developed largely in post-Third Terrace (Devensian) time. This indicates a degree of denudation in this period sufficient to form the Low Plain of Sparks (1957), a degree which may well have obliterated evidence for the landscapes of the Travellers' Rest Pit times in the area of the Gault outcrop, or which perhaps left the contamination of gravel and sand in the soil profiles of the Gault described by Hodge \& Seale (1966). This degree of denudation is a practical illustration of the effect of erosion of the Jurassic and Cretaceous vales of the region under a periglacial climate, such as must have occurred during the parts of the Wolstonian Stage before and after the Late Wolstonian Tottenhill Glaciation. Presumably the frost susceptible nature of Gault Formation clay made it vulnerable to brecciation by ice segregation and erosion by mass wasting.

An additional point of interest is the observation of Penning \& Jukes-Brown $(1881$, p.89) that "The ground where the gravel thinned out is about 80 feet ( $24 \mathrm{~m}$ O.D.) above sea level, but in the large pits near the farm, the base of the gravel is about 18 or $20(5-6 \mathrm{~m})$ feet lower." The gravel limit observed by Marr (Sedgwick Museum Archives) is shown in Figure 1. This suggests that an older valley of the Washpit Brook became occupied by gravels younger than those of the Travellers' Rest Pit following a period of incision, with the valley later moving westwards to its present position against the Gault Formation slope, implying more than one period of incision.

\section{Dating of the Travellers' Rest Pit Gravels and Observatory Gravels}

Worssam \& Taylor (1969) placed the Observatory Gravels and Head Gravel in a stage that was then known as the Gipping Glaciation. This term is now extinct and its place is taken by the Wolstonian Stage, in the latter part of which is the Tottenhill Glaciation of the Fenland (Gibbard et al. 1992, 2009). This dating would agree with the interpretation of the Travellers' Rest Pit Gravels suggested 
above. The dating is at odds with the dating of the Observatory Member to the Lowestoft Formation of the cold Anglian Stage reported by Bowen (1999). Boreham et al. (2010) reported the results of amino-acid D/L ratios (taxa used are unstated) from the Travellers' Rest Pit and the Terrace 4 Huntingdon Road Member, suggesting correlation with MIS 10-9 and 7-8. However, it is clear that the deposition of the Observatory Gravels must belong to a period of incision of the Gault Formation at times later than the deposition of the Travellers' Rest Pit Gravels (Appendix).

\section{Conclusions}

The Observatory Gravels of north-west Cambridge, representing an early period of fluvial gravel deposition in the Cam valley, are re-interpreted, following a study of the previous records of the area. The gravels are divided into those of the Travellers' Rest Pit, representing aggradation on a braid plain at c. 21-26 m O.D., of Late Wolstonian age and now on a ridge, and those of the west side of the ridge at a lower height, deposited as a valley developed in Gault Formation clay at times later in the Wolstonian Stage or in the Devensian Stage. It is concluded that the Observatory Gravels should be separated from the Travellers' Rest Pit gravels, with the formation of two units, one the Travellers' Rest (Gravels) Member, the other the Observatory (Gravels) Member (see appendix for definitions). Both units are included within the Cam Valley Formation.

The sequence in the Travellers' Rest Pit is described in detail and shows a major period of gravel aggradation, followed by a sheet of alluvial or colluvial fine sediments, associated with involutions, and a final minor period of aggradation. The deposits contain massive thermal contraction cracks, filled with finegrained sediments, and minor thermal contraction cracks within the gravels. The gravels, containing large boulders, are interpreted as identifying a former course of the River Cam, diverted westwards against the Gault Formation by glaciation in the Fenland, the Tottenhill Glaciation of Late Wolstonian age, and formed by the Cam drainage and possibly also meltwaters. The gravels contain a small shell fauna. They also contain Lower Palaeolithic artifacts, as do other Late Wolstonian proglacial deposits to the east and south of the Fenland. The Observatory Gravels, 3 to $4 \mathrm{~m}$ thick and on the western slope of the ridge, show pockets filled with contorted brown sand above and fine chalk-rich gravels irregularly bedded below, the Chalk derived from the Chalk Marl outcrop on the ridge above.

The re-interpretation assists in the recognition of processes associated with defining a southern and western limit of the Tottenhill Glaciation in the Fenland. It also confirms Penning \& Jukes-Brown's (1881) 
interpretation that the gravels represent the earliest evidence of the course of the River Cam, aligned towards the north-west through the gap at Oakington (NGR TL 420648).

Acknowledgements. The authors thank Sandra Freshney of the University of Cambridge Sedgwick Museum Archives, Steve Boreham for comment and discussion, and Philip Stickler (Department of Geography, University of Cambridge) for his cartographic expertise. They also thank Julian Murton, Jan Zalasiewicz and the editor Steve Donovan for their helpful reviews and editing of this article.

\section{Appendix: Stratigraphical classification}

Past descriptions of the Observatory Gravels and Travellers' Rest Pit Gravels of north-west Cambridge have grouped these deposits together as a single, internally complex lithostratigraphical unit. This was most recently proposed by Boreham (in Bowen 1999, p. 20), where the unit was included as a member of the Lowestoft Formation. However, as noted above, the gravel and sand sequences appear to represent two discrete units, the Traveller's Rest Gravels capping the ridge at Girton (stratotype: NGR TL 431599), whilst the Observatory Gravels (stratotype: NGR TL 431956) occur on the western slope of this ridge, at a lower elevation than the Travellers' Rest Pit spread. It is therefore proposed that the two units be separately classified as independent lithostratigraphical entities, both resting unconformably on Gault Formation bedrock.

Since the units are here interpreted as being associated to the drainage and valley development of the River Cam, and not to the Lowestoft Formation, they are here included in the Cam Valley Formation (Bowen 1999, p. 21). The units are assigned member status, the older unit referred to as the Traveller's Rest (Gravels) Member and the younger as the Observatory (Gravels) Member.

\section{References}

Boreham, S. 2002. The Pleistocene Stratigraphy and Palaeoenvironments of the Cambridge District. Unpublished Ph.D thesis. The Open University, Milton Keynes.

Boreham, S., w, T.S., Bridgland, D.R., Howard, A.J. \& White, M.J. 2010. The Quaternary history of the Wash fluvial network, U.K. Proceedings of the Geologists' Association, 121, 393-409. 
Bowen, D.Q. (Ed.) 1999. A revised correlation of the Quaternary Deposits of the British Isles. Geological Society Special Report No. 23.

Collinson, J.D. \& Thompson, D.B. 1982. Sedimentary Structures. Allen and Unwin, London.

Eyles, N., Eyles, C.H. \& Miall, A.D. 1983. Lithofacies types and vertical profile models; an alternative approach to the description and environmental interpretation of glacial diamict and diamictite sequences. Sedimentology, 30, 393-410.

French, H.M. 2007. The Periglacial Environment. $3^{\text {rd }}$ ed., Wiley, Chichester.

Gibbard, P.L. 1994. The Pleistocene history of the Lower Thames Valley. Cambridge University Press, Cambridge.

Gibbard, P.L., Pasanen, A.H., West, R.G., Lunkka, J.P., Boreham, S., Cohen, K.M., \& Rolfe, C. 2009. Late Middle Pleistocene glaciation in East Anglia, England. Boreas, 38, 504-528.

Gibbard, P.L., West, R.G., Andrew, R. \& Pettit, M. 1992. The margin of a Middle Pleistocene ice advance at Tottenhill, Norfolk, England. Geological Magazine, 129, 59-76.

Green, C.P. 2008. Travellers'Rest Pit, Girton, Cambridgeshire; Report on the field and laboratory investigations. Quaternary Scientific (QUEST) Unpublished Report; Project Number 031/08.

Hodge, C.A.H. \& Seale, R.S. 1966. The Soils of the District around Cambridge. Memoirs of the Soil Survey of Great Britain: England and Wales. Agricultural Research Council, Harpenden.

Leffingwell, E. de K. 1919. The Canning River region, Northern Alaska. Professional Papers of the U.S. Geological Survey, No. 109.

Lewin, J. \& Gibbard, P.L. 2010. Quaternary river terraces in England: forms, sediments and processes. Geomorphology, 120, 293-311.

Marr, J.E. 1920. The Pleistocene deposits around Cambridge. Quarterly Journal of the Geological Society of London, 75, 204-242.

Marr, J.E. 1926. The Pleistocene deposits of the Lower Part of the Great Ouse Basin. Quarterly Journal of the Geological Society of London, 82, 101-141.

Marr, J.E \& King, W.B.R. 1928. Notes on the Pleistocene deposits of the Cambridge District. Geological Magazine, 65, 307-312.

Marr, J.E. \& King, W.B.R.1932. Further notes on the Huntingdon Road Gravels, Cambridge. Geological Magazine, 69, 175-178.

Miall, A.D. 1977 A review of the braided river depositional environment. Earth Science Reviews 13, $1-62$.

Miall, A.D. 1978 Lithofacies types and vertical profile models in braided river deposits: a summary. In: A.D.Miall (Ed.), Fluvial sedimentology. Canadian Society of Petroleum Geologists Memoir 5, pp.597-604. 
Miall, A.D.1996 The Geology of fluvial sediments. Berlin, Springer-Verlag.

Mortimore, R.N., 2014. Logging the Chalk. Whittles Publishing, Dunbeath.

Murton, J.B., Bateman, M.D., Baker, C.A., Knox, R. \& Whiteman, C.A. 2003. The Devensian periglacial record in Thanet, Kent, UK. Permafrost and Periglacial Processes. 14, 217-246.

Paterson, T.T. 1940. The effects of frost action and solifluxion around Baffin Bay and in the Cambridge district. Quarterly Journal of the Geological Society of London, 96, 99-130,

Penning, W.H. \& Jukes-Brown, A.J. 1881. Geology of the neighbourhood of Cambridge. Memoirs of the Geological Survey of England and Wales. H.M.S.O., London,

Rastall, R.H. \& Romanes, J. 1909. On the boulders of the Cambridge drift. Quarterly Journal of the Geological Society of London, 65, 246-262.

Reed, F.R.C. 1897 A Handbook to the Geology of Cambridgeshire. Cambridge University Press.

Rust, B.R. 1978a A classification of alluvial channel systems. In: Miall, A.D. (ed.) Fluvial Sedimentology. Canadian Society of Petroleum Geology, Memoir 5, pp.187-198.

Rust, B.R. 1978b. Depositional models for braided alluvium. In: Miall, A.D. (ed.) Fluvial Sedimentology. Canadian Society of Petroleum Geology, Memoir 5, pp. 605-625.

Sparks, B.W. 1957. The evolution of the relief of the Cam Valley. The Geographical Journal, 123, 188-207.

Sparks, B.W. \& West, R.G., 1959. The palaeoecology of the interglacial deposits at Histon Road, Cambridge. Eiszeitalter und Gegenwart 10, 123-143.

Van Huissteden, J., Vandenberghe, J., Gibbard, P.L. \& Lewin, J. 2013. Periglacial Fluvial Sediments and Forms. In: Elias S.A. (ed.) The Encyclopedia of Quaternary Science, vol. 3, 490-499. Amsterdam: Elsevier.

West, R.G. 1993. Devensian thermal contraction networks and cracks at Somersham, Cambridgeshire, U.K. Permafrost and Periglacial Processes, 4, 277-300.

West, R.G. 2017. Patterned ground and superficial deposits at Hare Park, Swaffham Bulbeck, Cambridgeshire. Proceedings of the Yorkshire Geological Society. 62, .

Worssam, B.C. \& Taylor, J.H. 1969. Geology of the Country around Cambridge. Memoirs of the Geological Survey of Great Britain. H.M.S.O., London.

Wymer, J. 1985. Palaeolithic sites of East Anglia. Norwich, Geobooks. 
Figure captions.

1. Location map and geology of the study area, showing the position of profile A - B across the Travellers' Rest ridge from the valley of the Washpit Brook to the site of the Histon Road interglacial deposits (Ipswichian Stage) between the Gault bedrock and Terrace 3 gravels. The limit of gravel is taken from Marr's sketch plan of the Observatory and Travellers' Rest Pit area in the Sedgwick Museum Archives, and section C-D along the A14 road.

2. a. South-west to north-east profile across the Travellers' Rest ridge. b. North to south profile of the surface of mapped Head Gravel and Observatory Gravels and Terrace 4 of the Cam (BGS sheet 188).

3. Map of the Travellers' Rest Pit area. Symbol +: the area of Marr's sections (Marr 1920); 1, 2, the positions of Green's (2008) boreholes.

4. Marr's (1920) drawing of the section in the south pit of the Travellers' Rest Pit, vertical height 19 feet $(5.80 \mathrm{~m})$ (source: Quarterly Journal of the Geological Society of London, 75, 204-242).

The term 'series' is applied to the units of sands and gravels:

1. Lower evenly-bedded series.

2. Unevenly-bedded series.

3. Upper evenly-bedded series

4. Soil and 'warp'

The diagonal shading indicates pockets of loam and sections of 'pipes' from the 'warp' above. There is a gap of many yards ( metres) between the two sections. The section is at the southwest corner of the north-west face of the south pit at the above site. The dark line marks the boundary betwen the lower evenly-sands and gravels (1) and the unevenly-bedded sands and gravels (2). The sediment within the ice-wedge pseudomorphs in the sections includes the overlying loam (Marr 1920, p. 211).

5. Selected photographs of Travellers' Rest Pit sections from the Sedgwick Museum Archives: a. Fig. 4 shows the detail of the section. Catalogue number Fig. 11 (photograph by R.H. Rastall 1919). b. Detail of the upper part of the sequence (cf. Fig. 4). Catalogue number Fig. 12 (upper) (photograph by L.G. Morris 1920). c. Two generations of thermal contraction cracks beneath the involuted 'loam'. Catalogue number Fig. 11 (bottom) (photograph by R.H.Rastall 1919).

6. Marr \& King's (1932) diagrammatic section across the Traveller's Rest ridge (Girton) to Huntingdon Road, Cambridge (source: Geological Magazine, 69, 175-178).

7. Section along the Cambridge Northern By-pass road (A14), constructed from borehole records (source: BGS archive, 1971 survey). The line of the section is shown in Fig. 1 (C - D). 


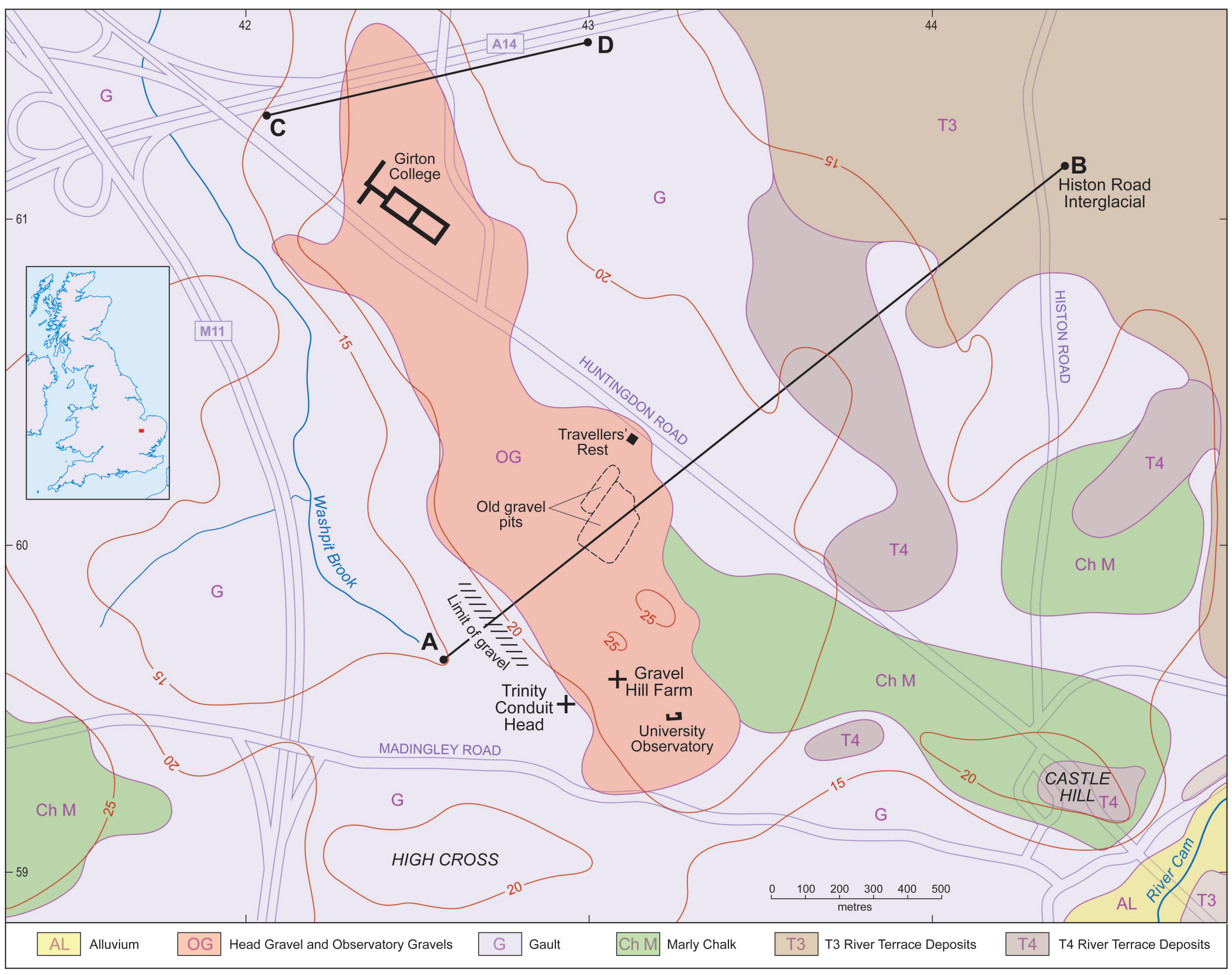


Washpit Brook

source area

SW

$15 \mathrm{~m}$ OD
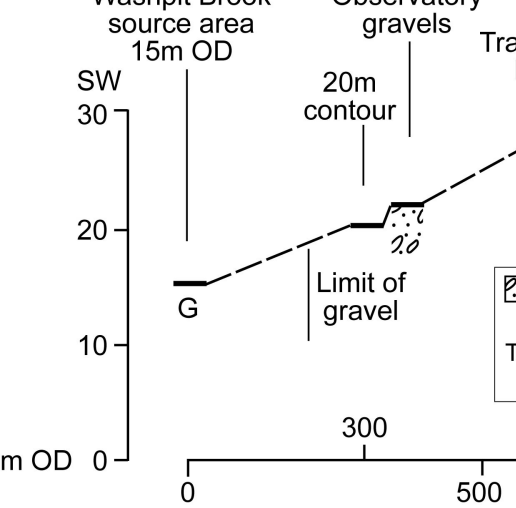

500

1280

1000

16801780

ig Interglacial (Ipswichian)

4/3 Terrace

600

1000

1

1500

$\stackrel{1}{1} 1$

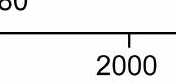

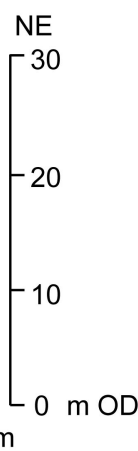




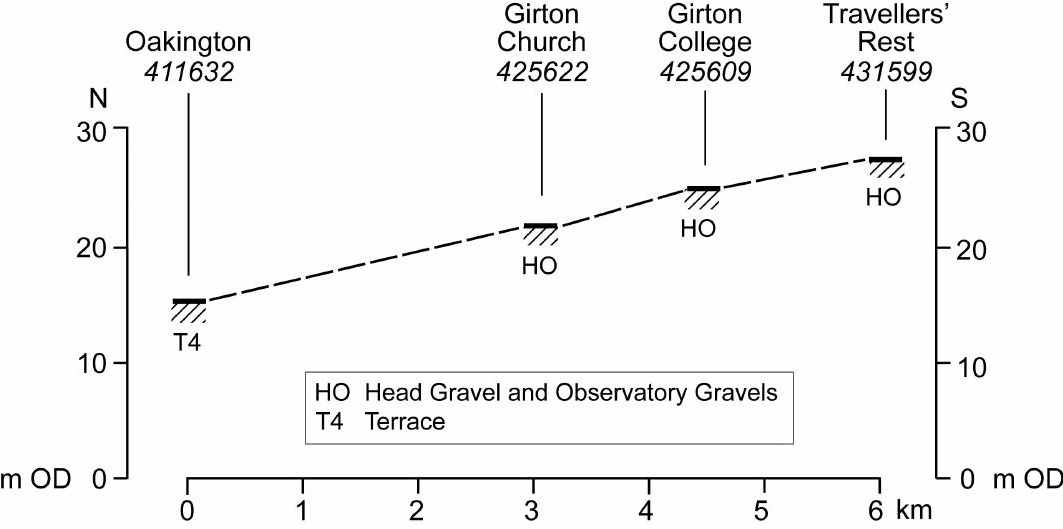




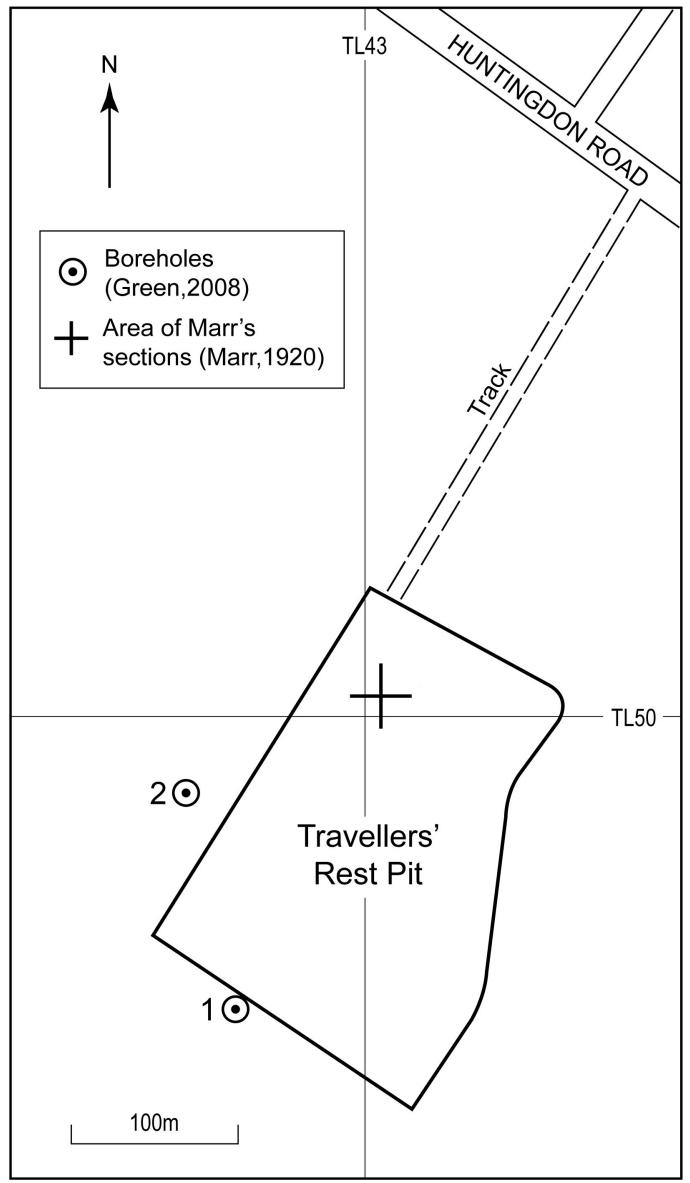


Fig. 2.-Sections in the south-western face of the South Pit, Traveller's Rest. (Vertical height=19 feet.)

4

3

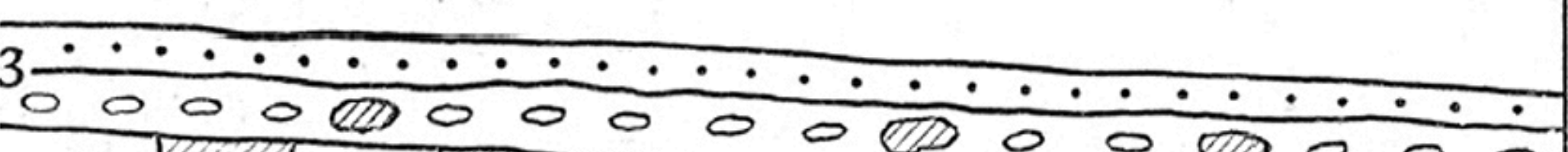
0 एय DV 0 एग - $\frac{1}{0} V_{0}^{0}$ $-\frac{0}{2}$ o $-0$ $\circ$
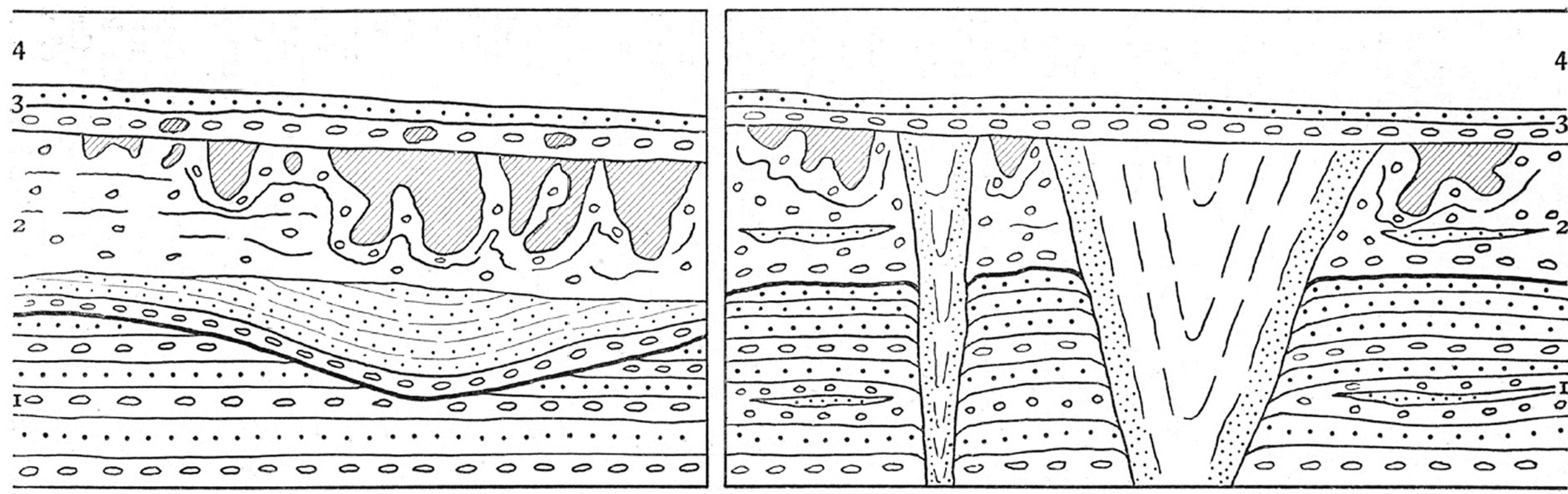

$1=$ Lower evenly-bedded series.

$3=$ Upper evenly-bedded series.

$2=$ Unevenly·bedded series.

$4=$ Soil and 'warp.' 
Traveller's Redt Pit.

Loam in everbedded Upper evenbedded

gravels yielding

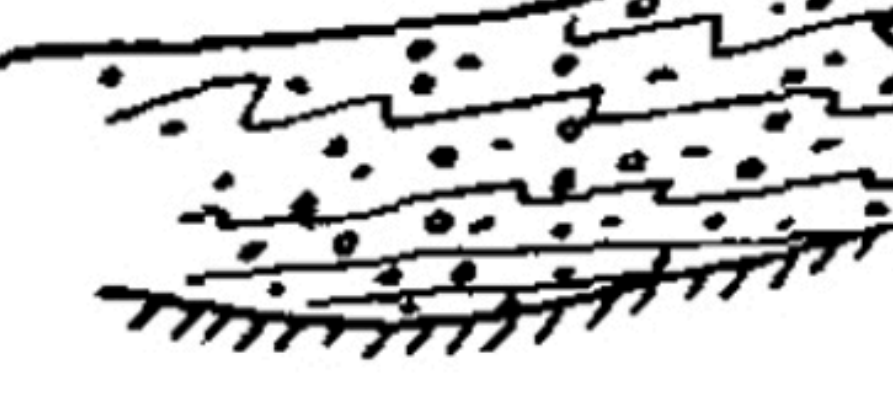

Gault
Looms or gravels yiciding. coenlicopia

\section{Fia. 3.-Diagrammatic section across the Huntingdon Road, Cambridge.}


Girton Road bridge

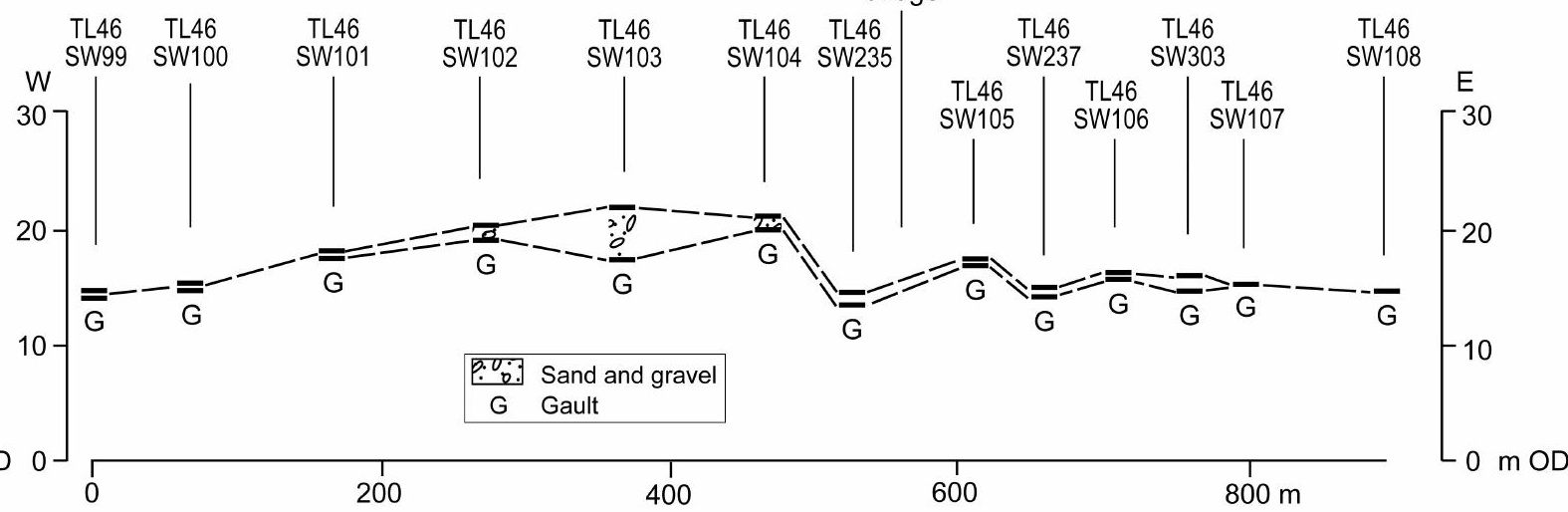

